determined as a function of the temperature and of the surface concentration.

The diffusion of gases through solids is controlled partly by the interaction of the gas with the surface and partly by processes occurring in the body of the solid, both of these in general being specific, for example, $\mathrm{H}_{2}-\mathrm{Pd}, \mathrm{O}_{2}-\mathrm{Ag}, \mathrm{N}_{2}-\mathrm{W}$. An exception to the rule is the diffusion of hydrogen, helium, neon, argon, nitrogen and oxygen through silica glass ${ }^{3}$. There is no doubt in the case of the inert gases that the forces which the atoms encounter in their passage through silica are purely of the van der Waals' type. In fact, it may be shown by calculation that the energy of activation for the passage of an inert gas atom through a square of similar atoms can attain values commonly associated with chemical reactions, such as 30 kgm. cal. Migration appears to take place through the solid lattice, for the rate is independent of the firing and other treatment of the silica. With oxygen and nitrogen, on the other hand, the rate is very sensitive to surface imperfections, firing and the like, which would point to the diffusion occurring along slip-planes and cracks in the glass.
Much has been written about the usefulness of deuterium as a tool for investigating the mechanism of chemical reactions. Taken along with the orthopara conversion, the behaviour of deuterium yields important evidence about catalytic hydrogenation and dehydrogenation reactions. For example, if ammonia and ortho deuterium are allowed into contact with an iron catalyst, A. Farkas has found that the rate of conversion of the ortho deuterium is inhibited by the ammonia, and simultaneously there is a slow exchange reaction resulting in the production of deuterammonia. This shows at once that ammonia partially covers the iron surface, that deuterium is dissociated on the portions not covered with the ammonia, and that the rate of exchange is slower than the dissociation of deuterium molecules, the latter reaction therefore not being the rate-determining step.

These few examples suffice to demonstrate that the field of inquiry is an extending one, and that well-defined progress is being made in drawing a more precise picture of the interaction of gases with solids.

${ }^{1}$ Proc. Roy. Soc., A, 152, 445; 1935.

2 Proc. Roy. Soc., A, 150, 58; 1935.

${ }^{3}$ R. M. Barrer, J. Chem. Soc., 378: 1934

\title{
Obituary
}

\section{Mr. F. Escombe}

$\mathrm{E}$ VERY student and teacher of botany must be familiar with the classic work of Brown and Escombe on the germination of refrigerated seeds; the relative roles of endosperm and embryo in germinating barley; on the static diffusion of gases and liquids in relation to photosynthesis and translocation in plants; the influence of varying amounts of atmospheric carbon dioxide on photosynthesis and plant growth ; the interchange of energy between the leaf and its surroundings; the determination of carbon dioxide in the air absorbed by plants, based on the rate of its absorption by a free surface of a solution of caustic alkali ; and they will learn with regret of the sudden death of the surviving author of these important researches on October 12. Brown, who was a much older man, died in 1925. Fergusson Escombe, who was only sixty-three years of age, had given up his active career at a comparatively early age owing to ill-health and other circumstances, and thus, though his work will always hold a high place in botanical research, he himself had almost been forgotten, save by a few.

Born in Hampshire in 1872, Escombe went to a preparatory school at Bournemouth and thence to Haileybury for two years. He matriculated in 1892 , and later obtained the degree of B.Se., with honours in botany, at the University of London, from King's College, London. There he won the Carter Gold
Medal and Prize for botany. He studied also at Downton Agricultural College, at Neuenheim College, Hoidelberg, and at the Kaiser Wilhelm University at Strassburg. Whilst at the latter, he worked on the chemistry of the cell membranes of lichens and fungi, and published a paper on it in 1896, "Beitrag zur Chemie der Membranen der Flechten und Pilze" (Hopp.-Seyl. Z. Phys. Chem., 22, 288-306 ; 189697), a preliminary investigation to determine the existence of chitin and cellulose in these groups. This showed his early leaning towards bio. ehemistry.

Shortly afterwards, Escombe went to work with Brown at the Jodrell Laboratory, Kew, on the researches which were published jointly in the Royal Society Proceedings and Philosophical Transactions, 1897-1905, and which gained for Escombe an established place in botanical science. There is no necessity to summarise these researches-indeed it would be quite impossible except at great lengthsince they have passed into botanical history and are described in every botanical textbook. They marked, however, a great advance in the state of knowledge then of the essentials of the physiological processes of germination and nutrition. Being reduced to mathematical precision, the results were enunciated so that in some cases they could be stated in formulæ. Special methods and apparatus had to be devised to carry out such delicate experiments, and novel 
methods of study adopted to demonstrate the physical laws that controlled plant activity.

Following these fine contributions to biochemical and biophysical science, both Brown and Escombe took up appointments in the Scientific Research Laboratory of Messrs. Guinness and Co. at Dublin, Brown as director and Escombe as vegetable physiologist. The work on improving the malting qualities of barley was published (unsigned) in the Laboratory Transactions. Escombe worked there from July 1901 for three years. Readers of NATURE will remember the excellent reviews by Escombe on German biochemical works by Emmerling, Schulz, Czapek and Wieler about this time (1902-6). He wrote for Science Progress, 1897-98, two papers on germination generalised from the Royal Society researches.

Escombe then held the post of lecturer in botany and head of the Botanical Department at the SouthEastern Agricultural College, Wye, following Mr. (now Sir) Albert Howard, and at the same time gave County Council lectures in Kent and Surrey. $\mathrm{He}$ was at Wye from July 1905 until July 1907. This ended his active career at the age of thirty-five. $\mathrm{He}$ returned to Kow to do some physiological work at the Jodrell Laboratory in March and April 1910. After that, save for work during the Great War at the Admiralty (1917-22), he retired, from ill-health and other circumstances, to his native county, Hamp. shire (where also lived his great friend, Dr. D. H. Scott), living with his family, and latterly, since 1929, in rooms at East Meon, where he made his home until his death.

There Escombe took an active part in the life of the village, and his chief hobbies were reading and walking, and exploring the flora and fauna of the district. He studied the two Arums, and carried out an exhaustive series of researches on their life-history and ecology, later studying that difficult group of trees, the elms. In both cases he wrote valuable notes upon the species, which, with excellent material, he sent to Kew. He also there wrote a treatise on

'Buds in Winter'. All these should be published posthumously, since they are characterised by the same masterly grasp of details, and the clear and well-conceived enunciation of principles, or of classification, with brilliant and sound analogy, which marked the Royal Society papers published in conjunction with Brown.

Fergusson Escombe was a very reserved man, and of a refined nature. Properly understood, he was a charming companion. He had a most gentle nature, and a great love of animals and for children and old people. His scientific work was characterised by thoroughness and avoidance of hurry, and his experiments were conducted with carefulness and exactitude. It seems a tragedy that a man gifted by Nature with exceptional scientific ability, enlarged by special training, and with so sound a knowledge of biochemistry and physiology, should have had to disappear, through ill-health, from the arena of science at so early an age. Ill-health caused his career to be prematurely shortened, and heart failure has now snatched him from the world, his relations and friends all too soon.

\section{Senator Paolo Orsi}

WE regret to record the death of Senator Paolo Orsi, the distinguished Italian archæologist, which took place at Rovereto on November 8 at the age of seventy-six years.

Paolo Orsi was born in 1859 at Rovereto, which was then Austrian territory, but on completing his studies he settled in Italy. In 1888 he became an inspector of the Museum of Syracuse, and soon afterwards was appointed its director. He applied himself to the exploration of the antiquities of the island of Sicily, and by his discoveries revealed the sequence of Siculan culture from early chalcolithic times down to the period of Greek colonisation, a sequence in which he showed that four separate types of civilisation were to be distinguished. His excavations, more particularly in the neolithic villages of Stentinello, the burial grounds of Megara near Syracuse, and at Gela, made his museum one of the richest, and in some respects of the first importance, for the study of certain aspects and periods of Mediterranean archæology.

In 1907, Orsi was appointed superintendente of Calabria and Basilicata. Here he continued his investigations and discovered the pre-Hellenic sites of Torre Galli, near Monteleone, and of Canale, near Locri, both of crucial importance for the study of the prehistory of the Calabrian peninsula. He undertook a number of excavations under the auspices and mainly at the expense of the Societa Magna Græcia, of which he was president at the time of his death. Among his discoveries was that of an Ionic temple at Locri, the only known example in Magna Græcia. The material from these excavations will be exhibited in a museum now in course of construction at ReggioCalabria. He was also an authority on Byzantine antiquities, which he had studied in both Sicily and Calabria.

At the close of the Great War, Orsi took up his residence in retirement at Rovereto. $\mathrm{He}$ was a member of the Accademia dei Lincei, and was made a Senator in 1924. He was an honorary member of the Society for the Promotion of Hellenic Studies and an honorary fellow of the Royal Anthropological Institute.

\section{WE regret to announce the following deaths :}

Prof. James H. Breasted, professor of Egyptology and oriental history in the University of Chicago from 1905 until 1933, and director of the Oriental Institute, Chicago, on December 2, aged seventy years.

Prof. J. D. Cormack, C.M.G., C.B.E., regius professor of civil and mechanical engineering in the University of Glasgow, on November 30, aged sixtyfive years.

Prof. David C. Gillespie, professor of mathematics in Cornell University, for several years editor of the American Mathematical Monthly, on October 13, aged fifty-seven years.

Prof. J. E. A. Steggall, emeritus professor of mathematics at University College, Dundee, in the University of St. Andrews, on November 26, aged eighty years. 